\title{
Does the FIFA 11+ Program Prevent Hamstring Injuries in College-Aged Male Soccer Players? A Critically Appraised Topic
}

\author{
Scott Benson Street and Thomas Kaminski
}

\begin{abstract}
Clinical Scenario: Hamstring injuries are the most prevalent lower-extremity injury among soccer players. The Fédération Internationale de Football Association (FIFA) has addressed this issue by developing the FIFA 11+ program, which is focused on improving strength and decreasing the incidence of lower-extremity injuries in the sport. This critically appraised topic focuses on this program as well as one of its components, the Nordic hamstring exercise, in the prevention of hamstring injuries. Clinical Question: Does the FIFA 11+ program prevent hamstring injuries in college-aged male soccer players? Summary of Key Findings: Four studies were selected to be critically appraised. The PEDro checklist was used to score the articles on methodology and consistency. All 4 articles demonstrated support for the clinical question. Clinical Bottom Line: There is moderate evidence to support the use of the FIFA 11+ program and Nordic hamstring exercise as part of a college soccer team's warm-up routine. Strength of Recommendation: Grade B evidence exists in support of incorporating the FIFA 11+ program to reduce the incidence of hamstring injuries in male college soccer players.
\end{abstract}

Keywords: lower extremity, biomechanics, thigh, intercollegiate, Nordic hamstring exercise

\section{Clinical Scenario}

With over 275 million people worldwide participating in soccer, ${ }^{1}$ musculoskeletal injuries occur frequently. There are approximately 23,000 college male soccer players participating in NCAA soccer. ${ }^{2}$ Hamstring injuries are the most prevalent musculoskeletal injury among athletes participating in the sport of soccer, accounting for $12 \%$ to $16 \%$ of all injuries. ${ }^{3}$ The Fédération Internationale de Football Association (FIFA) has developed a warm-up program known as the FIFA 11+, with the focus of improving strength and reducing the incidence of lower-extremity injuries that soccer players suffer. ${ }^{2}$ One of the exercises included in the FIFA 11+ program is the Nordic hamstring exercise (NHE), meant to improve the strength of the hamstring muscle group. ${ }^{4}$

Due to the lack of literature available on the FIFA 11+ and female soccer athletes, this critically appraised topic is focused on male athletes. Professional women's soccer leagues have recently started up around the world, thus providing research opportunities to determine the efficacy of the FIFA $11+$ program for female athletes.

\section{Focused Clinical Question}

Does the FIFA 11+ program prevent hamstring injuries in collegeaged male soccer players?

\section{Summarized Key Findings}

- The literature was searched for level 2 evidence or higher that investigated the effects of the FIFA 11+ or NHE on hamstring injury rates in male college soccer players.

Street is with West Virginia Wesleyan College, Buckhannon, WV, USA. Kaminski is with the University of Delaware, Newark, DE, USA. Street (street_s@wvwc.edu) is corresponding author.
- The literature search returned 11 possible studies related to the clinical question; 4 studies met the inclusion criteria.

- Three randomized controlled trials and 1 cohort study were included.

- All included studies reported a reduction in hamstring injury as a result of incorporating the FIFA $11+$ program or NHE into the warm-up routine compared with not incorporating them.

\section{Clinical Bottom Line}

There is moderate evidence to support the use of the FIFA 11+ program and NHE as part of a college soccer team's warm-up routine.

\section{Strength of Recommendation}

Grade B evidence exists in support of incorporating the FIFA 11+ program to reduce the incidence of hamstring injuries in male college soccer players.

\section{Search Strategy}

\section{Terms Used to Guide Search Strategy}

- Patient/Client group: College-aged male soccer players

- Intervention (or Assessment): FIFA 11+ program or NHE

- Comparison: Control group (did not perform FIFA 11+ or NHE)

- Outcome(s): Reduction in hamstring injury incidence

Sources of Evidence Searched (Databases)

- PubMed

- SPORTDiscus

- Google Scholar

- Additional resources obtained via review of reference lists 


\section{Inclusion and Exclusion Criteria}

\section{Inclusion Criteria}

- Studies that investigated hamstring injuries in college-aged male soccer players

- Studies that used the FIFA $11+$ or NHE as an intervention

- Limited to the English language

- Limited to the past 10 years (2010-2019)

- Level 2 evidence or higher

\section{Exclusion Criteria}

- Studies that did not report hamstring injury incidence rate

- Participants who were not college age $(<17$ and $>25$ y)

\section{Results of Search}

Four relevant studies were located and categorized, as shown in Table 1.

\section{Summary of Best Evidence}

Characteristics of studies identified as the best evidence are shown in Table 2.

\section{Implications for Practice, Education, and Future Research}

All 4 studies demonstrated a reduction in hamstring injury incidence $^{1-3,5}$; however, only 2 randomized controlled trial studies

Table 1 Summary of Study Designs of Articles Retrieved

\begin{tabular}{llcl}
\hline Level of evidence & Study design/methodology & Number located & Study \\
\hline $1 \mathrm{~b}$ & Randomized controlled trial & 2 & Silvers-Granelli et al ${ }^{2}$ and Petersen et al $^{3}$ \\
$2 \mathrm{a}$ & Randomized controlled trial & 1 & van der Horst et al \\
$2 \mathrm{~b}$ & Cohort study & 1 & Grooms et al $^{5}$ \\
\hline
\end{tabular}

Table 2 Characteristics of Studies Identified as the Best Evidence

\begin{tabular}{|c|c|c|c|c|}
\hline & Silvers-Granelli et $\mathrm{al}^{2}$ & Petersen et $\mathrm{al}^{3}$ & van der Horst et al ${ }^{1}$ & Grooms et $\mathrm{al}^{5}$ \\
\hline Study design & Randomized controlled trial & Randomized controlled trial & Randomized controlled trial & Prospective cohort \\
\hline Participants & $\begin{array}{l}65 \text { NCAA DI and DII men's } \\
\text { college soccer teams } \\
\text { (1525 players) }\end{array}$ & $\begin{array}{l}50 \text { Danish male professional } \\
\text { and amateur soccer teams } \\
\text { (942 players) }\end{array}$ & $\begin{array}{l}\text { Male amateur soccer players } \\
\text { from } 40 \text { teams ( } 579 \text { players) }\end{array}$ & $\begin{array}{l}\text { One American college men's } \\
\text { soccer team. }\end{array}$ \\
\hline $\begin{array}{l}\text { Intervention } \\
\text { investigated }\end{array}$ & FIFA $11+$ & NHE & NHE & F-MARC 11+ (FIFA 11+) \\
\hline $\begin{array}{l}\text { Outcome } \\
\text { measure(s) }\end{array}$ & $\begin{array}{l}\text { Lower-extremity injury inci- } \\
\text { dence rate and total days missed } \\
\text { due to lower-extremity injury }\end{array}$ & $\begin{array}{l}\text { Acute hamstring injury inci- } \\
\text { dence rate }\end{array}$ & Hamstring injury incidence rate & $\begin{array}{l}\text { Lower-extremity injury risk and } \\
\text { time lost to lower-extremity } \\
\text { injury. }\end{array}$ \\
\hline $\begin{array}{l}\text { Main } \\
\text { findings }\end{array}$ & $\begin{array}{l}\text { Incidence rate }=15.04 / 1000 \mathrm{AE} \\
\text { in the control group and } 8.09 / \\
1000 \mathrm{AE} \text { in the intervention } \\
\text { group. There were } 55 \text { hamstring } \\
\text { injuries in the control group } \\
(\mathrm{IR}=1.244) \text { vs } 16 \text { in the inter- } \\
\text { vention group (IR }=0.454) \text {. }\end{array}$ & $\begin{array}{l}\text { Overall acute hamstring injury } \\
\text { rates were } 3.8 / 100 \text { player sea- } \\
\text { sons in the intervention group } \\
\text { and } 13.2 / 100 \text { player seasons in } \\
\text { the control group. New ham- } \\
\text { string injuries occurred with an } \\
\text { incidence rate of } 3.1 / 100 \text { player } \\
\text { seasons in the intervention } \\
\text { group and } 8.1 / 100 \text { player sea- } \\
\text { sons in the control group. }\end{array}$ & $\begin{array}{l}\text { Injury incidence rate was } 0.25 / \\
1000 \text { player hours in the inter- } \\
\text { vention group and } 0.8 / 1000 \\
\text { player hours in the control } \\
\text { group. }\end{array}$ & $\begin{array}{l}\text { The muscle strain injury rate } \\
\text { in the referent season was } 6.2 \text { / } \\
1000 \mathrm{AE} \text {. In the intervention } \\
\text { season, muscle strain injury rate } \\
\text { was } 0.55 / 1000 \mathrm{AE} \text {. Time lost to } \\
\text { thigh muscle strain in the } \\
\text { intervention season was less } \\
\text { than the referent season. }\end{array}$ \\
\hline $\begin{array}{l}\text { Level of } \\
\text { evidence }\end{array}$ & $1 b$ & $1 \mathrm{~b}$ & $2 \mathrm{a}$ & $2 \mathrm{~b}$ \\
\hline $\begin{array}{l}\text { Validity } \\
\text { score } \\
\text { (PEDro) }\end{array}$ & $6 / 10$ & $6 / 10$ & $5 / 10$ & N/A \\
\hline Conclusion & $\begin{array}{l}\text { FIFA } 11+\text { significantly reduced } \\
\text { injury rates by } 46.1 \% \text { and } \\
\text { decreased time loss to injury by } \\
28.6 \% \text { in the competitive male } \\
\text { college soccer player. }\end{array}$ & $\begin{array}{l}\text { In male professional and ama- } \\
\text { teur soccer players, additional } \\
\text { eccentric hamstring exercise } \\
\text { decreased the rate of overall, } \\
\text { new, and recurrent acute ham- } \\
\text { string injuries. }\end{array}$ & $\begin{array}{l}\text { Incorporating NHE in regular } \\
\text { training significantly reduces } \\
\text { hamstring injury incidence; } \\
\text { however, it does not reduce } \\
\text { hamstring injury severity. }\end{array}$ & $\begin{array}{l}\text { The F-MARC } 11+\text { program } \\
\text { reduced overall risk and sever- } \\
\text { ity of lower-extremity injury } \\
\text { compared with controls in col- } \\
\text { lege-aged male soccer athletes. }\end{array}$ \\
\hline
\end{tabular}

Abbreviations: AE, athletic exposure; DI, division I; DII, division II; FIFA, Fédération Internationale de Football Association; F-MARC, FIFA Medical Assessment and Research Centre; IR, incidence rate; N/A, not applicable; NCAA, National Collegiate Athletic Association; NHE, Nordic hamstring exercise; PEDro, physiotherapy evidence database. 
reported their findings as significant. ${ }^{1,2}$ While the evidence suggests that the FIFA $11+$ program reduces hamstring injury incidence rate, limited findings on the severity of the hamstring injuries were reported. ${ }^{1}$ None of the studies included demonstrated an increase in lower-extremity/hamstring injuries due to the FIFA 11+ program or NHE performance.

Based on the included studies, college-aged male soccer players may benefit from performing the FIFA 11+ program during warm-up for training and competition, or from including NHE in their strength training regimen. ${ }^{1-3,5}$ While these findings may be the result of methodological differences across studies, such as study design or the type of exercise included, it may also be a component of how often the exercise was performed. There was an inconsistency in the number of times the exercises were performed during each week, as well as the number of sets and repetitions performed among the studies.

One of the included studies performed an analysis of numbers needed to treat (NNT) to identify how many athletes would need to perform NHE (27 sessions over a 10-wk period) to prevent a hamstring injury. ${ }^{3}$ The study reported that the NNT to prevent 1 acute hamstring injury (new or recurrent) was 13 players. ${ }^{3}$ It was also reported that the NNT to prevent 1 new hamstring injury was 25 players, and that the NNT to prevent 1 recurrent injury was 3 players. $^{3}$

One possible project for future research could determine sets, repetitions, and number of days that FIFA 11+ or NHE are performed in order to maximize their benefit. Future research should also explore the preventative effect of the FIFA $11+$ or NHE on male youth athletes ( $<17$ y old), adult male athletes $(>25 \mathrm{y}$ old), and female athletes. Furthermore, identifying athletes in other sports (eg, basketball, American football) who may benefit from this intervention would enhance its overall incorporation. This critically appraised topic should be reviewed in 2 years or when additional evidence becomes available that may alter the clinical bottom line for this clinical question.

\section{Acknowledgment}

The authors declare no conflict of interest.

\section{References}

1. van der Horst N, Wouter Smits D, Petersen J, Goedhart E, Backx F. The preventive effect of the Nordic hamstring exercise on hamstring injuries in amateur soccer players: a randomized controlled trial. $\mathrm{Br} \mathrm{J}$ Sports Med. 2014;48(7):609-610. doi:10.1136/bjsports-2014-093494. 135

2. Silvers-Granelli H, Mandelbaum B, Adeniji O, et al. Efficacy of the FIFA $11+$ injury prevention program in the collegiate male soccer player. Am J Sports Med. 2015;43(11):2628-2637. PubMed ID: 26378030 doi:10.1177/0363546515602009

3. Petersen J, Thorborg K, Nielsen MB, Budtz-Jørgensen E, Hölmich P. Preventive effect of eccentric training on acute hamstring injuries in men's soccer: a cluster-randomized controlled trial. Am J Sports Med. 2011;39(11):2296-2303. PubMed ID: 21825112 doi:10. $1177 / 0363546511419277$

4. Mjolsnes R, Arnason A, Østhagen T, Raastad T, Bahr R. A 10-week randomized trial comparing eccentric vs. concentric hamstring strength training in well-trained soccer players. Scand J Med Sci Sports. 2004;14(5):311-317. PubMed ID: 15387805 doi:10.1046/j. 1600-0838.2003.367.x

5. Grooms DR, Palmer T, Onate JA, Myer GD, Grindstaff T. Soccerspecific warm-up and lower extremity injury rates in collegiate male soccer players. J Athl Train. 2013;48(6):782-789. PubMed ID: 23848519 doi:10.4085/1062-6050-48.4.08 